\title{
Study on the Validity of Recently Introduced Wrist Watch Type Heart Rate Monitoring Device
}

\author{
Seunghoon Yoo
}

Department of Pediatric Dentistry, School of Dentistry, Dankook University

\begin{abstract}
There are several ways to analyse stress resulting from anxiety and fear within dental treatment for children. Surveying questionnaires and monitoring biologic reaction are the most common ways for evaluating stress. Pulse oximeter is a popular device for detecting heart rate but not appropriate for moving children. In this study, we compared a recently introduced wrist- watch type heart rate monitor(Alpha, MIO, USA) with a pulse oximeter(MP110, MECKIS, Republic of Korea) for 10 attendants with two conditions including resting state and excited state after exercise. Data were analyzed using Wilcoxon Signed Rank test and there is no statistical difference between two devices $(p<0.05)$.
\end{abstract}

Key words : Stress, Heart rate, Wrist watch type heart rate monitor

\section{I. 서 론}

소아 환자가 치과 진료실에서 받는 스트레스는 성인들에 비 해서 더 많은 것으로 알려져 있다 ${ }^{11}$. 소아치과에서 소아 환자가 보이는 불안감은 울음, 발버둥 등의 부정적인 행동양상으로 표 출되며 치과 진료의 결과에 영향을 줄 수 있다.

환자가 치과 진료실에서 받는 불안과 공포에 관한 다양한 연 구가 있었다 ${ }^{1-6)}$. 불안과 공포를 평가하기 위해 이를 수치화하기 위한 노력과 함께 이로 인하여 발생하는 스트레스를 측정하기 위한 다양한 연구가 있었다.

Cuthbert 등)이 제안한 CFSS-DS(th children's fear survey schedule dental subscale)은 가장 많이 이용되는 평가법 이다. 이러한 연구의 목적은 환아가 치과진료를 받는데 방해가 되는 행동 양상을 제거하기 위한 것만이 아닌 스트레스를 유발 하는 불안과 공포의 원인을 이해하고 그것으로 인한 거부감을 최소화시키기 위한 것이다.

이러한 스트레스를 측정하기 위한 방법으로 치료 시작 전 혹 은 치료 종결 후 환자 혹은 환자의 보호자에게 설문지를 작성하 도록 하는 방법 ${ }^{11}$ 과 환자의 생체 반응을 측정하는 방법이 있다.
특히 스트레스에 따른 심박수와 혈압의 변화에 관한 연구가 있 었다 ${ }^{5-7,9-11)}$. 설문지를 작성하는 방법은 치료와 동시에 진행되지 않으며 주관적인 평가나 기억력에 의존해야 하는 이유로 객관 성이 낮다. 최근에는 환자의 생체 반응에서 혈압과 심박수의 변 화에 관심이 집중되고 있으며 특히 심박수의 변화 양상의 관찰 이 주목받고 있다.

환자의 심박수를 측정하기 위한 상대적으로 저렴하고 쉽게 사용 가능한 기기로 포화도 측정기(pulse oximeter)가 있다. 산소 포화도 측정기는 혈액내의 산소 포화도와 함께 심박수를 측정하며 LED(light emitting diode) 센서가 장착된 probe에 손가락이나 발가락을 끼워 생체 반응을 측정한다. 이러한 장착 방법은 운동성이 없는 환자를 전제로 하며 움직임에 의하여 probe가 쉽게 탈락하고 이로 인하여 신호가 중단되는 문제가 있다.

최근에는 손목 시계 형태로 손목에 장착하여 지속적으로 심 박수를 측정할 뿐 아니라 움직임에 의한 신호의 중단 가능성을 제거한 장비가 소개되었다. 이번 연구를 통하여 손목 시계 형태 의 심박수 측정 장치가 기존의 산소 포화도 측정기와 비교하여 유용한가를 확인해 보고자 하였다.

\section{Corresponding author: Seunghoon Yoo}

Department of Pediatric Dentistry, School of Dentistry, 119 Dandaero, Dongnam-gu, Cheonan, 330-714, Korea

Tel: +82-41-550-0222 / Fax: +82-41-550-0118 / E-mail: yoo.seunghoon@gmail.com

Received January 28, 2014 / Revised February 6, 2014 / Accepted February 6, 2014

※ This present research was conducted by the research fund of Dankook University in 2012. 


\section{II . 연구 재료 및 방법}

\section{1. 대상}

실험 참여 대상은 24 세에서 33세까지 연령(평균 28.8세, 표 준편차 3.36)의 성인 10 명을 대상으로 하였으며 문진결과 심혈 관계 질환이 있는 자는 배제하였다.

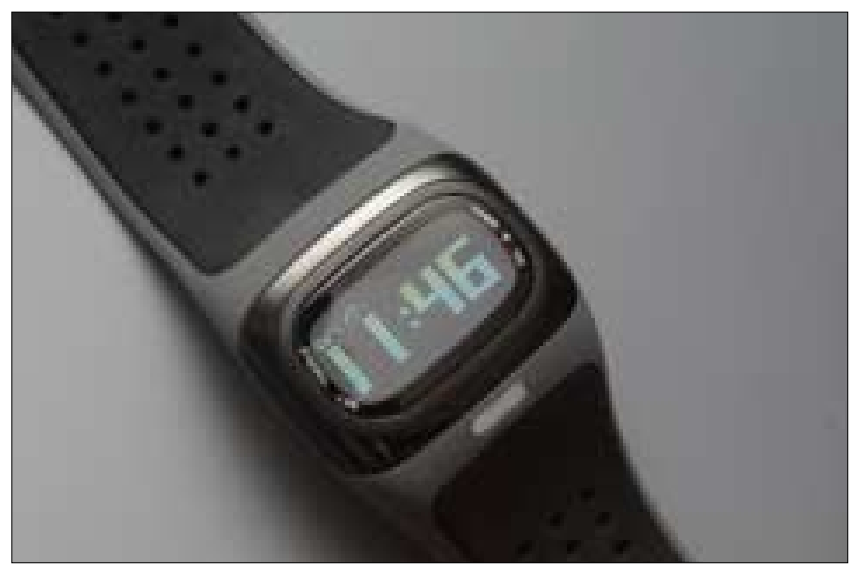

Fig. 1. Frontal face of Mio Alpha.

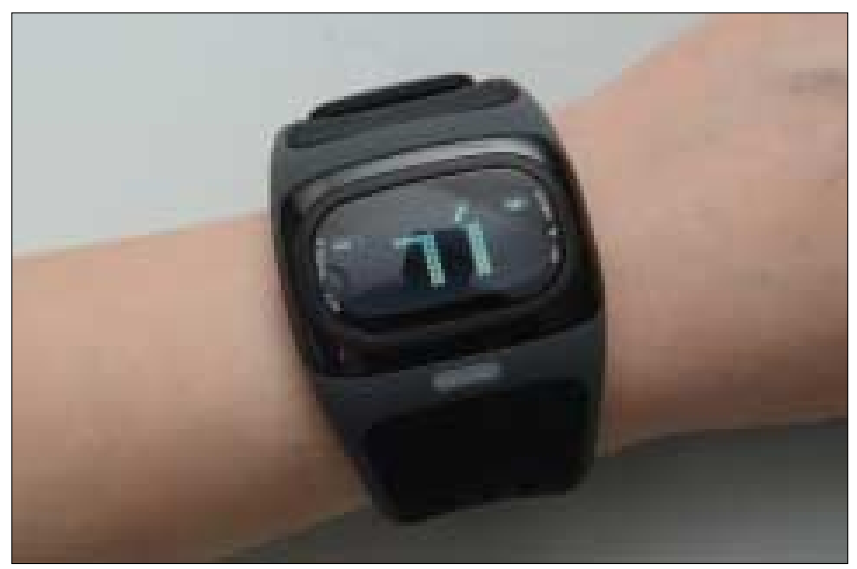

Fig. 3. Alpha showing heart rate per minute.

\section{2. 재료}

손목형 심박수 측정 장치는 Alpha(MIO, USA) (Fig. 1, 2, 3)를 이용하였다. 손목 시계 형태로 손목에 장착하여 심박수를 측정한다.

포화도 측정기는 MP110(MEKCIS, Republic of Korea) (Fig. 4)를 이용하였으며 probe형 LED 센서가 장착된 것을 이 용하였다.

$\mathrm{MIO}$ 사의 Alpha와 MP110의 사양표 다음과 같다(Table 1).

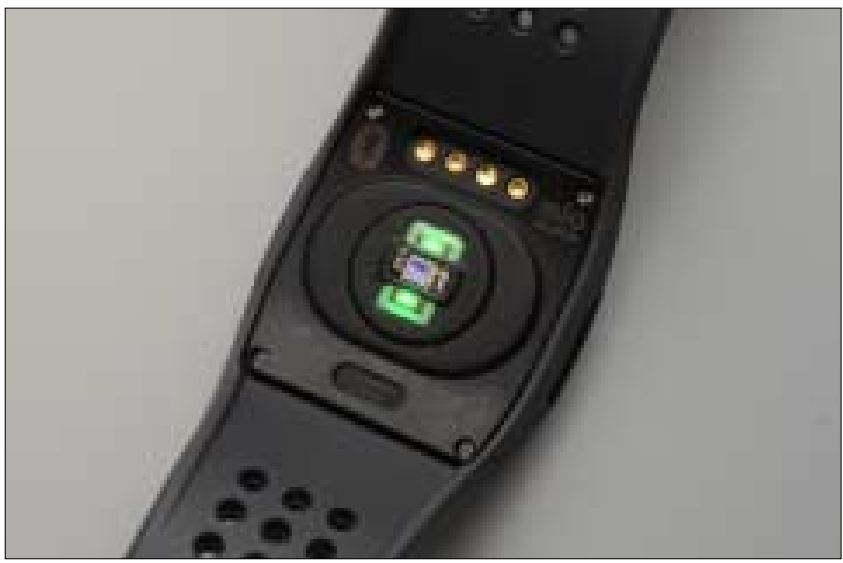

Fig. 2. Back face showing light emitting diode sensors for detecting heart rate

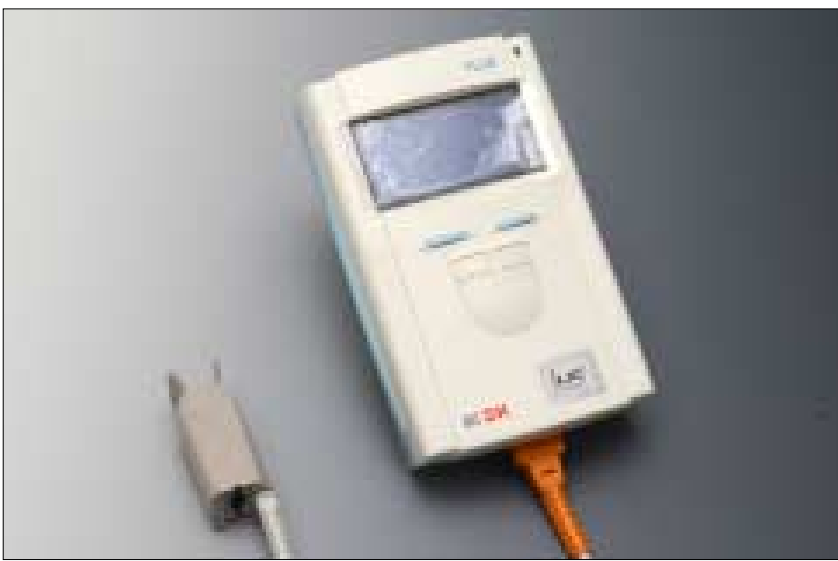

Fig. 4. MP110 pulse oximeter with probe.

Table 1. Technical specifications of Alpha and MP110

\begin{tabular}{lll}
\hline & \multicolumn{1}{c}{ MP110 } & \multicolumn{1}{c}{ Alpha } \\
\hline Display & backlight mono LCD & negative dot-matrix LCD \\
Operation & frontal 4 buttons & intuitive 2 button navigation \\
Sensor & LED sensor at probe terminal & Tri-color LED heart rate zones \\
Data Transmitting method & none & Bluetooth ${ }^{\circledR}$ Smart wireless transmitter \\
Battery & rechargeable battery last 8 hrs. & $170 \mathrm{mAh} \mathrm{lithium} \mathrm{polymer} \mathrm{rechargeable} \mathrm{battery}$ \\
& & USB charging dock with magnetic alignment \\
\hline
\end{tabular}




\section{3. 방법}

자연스럽게 무릎이 접히는 상태의 의자에 5 분 이상 앉아 안 정 상태를 유지한 참가자의 심박수와 운동 직후의 심박수를 각 각 10 초 간격으로 3 분간 측정하였다. 운동 직후의 심박수 측정 은 피검자가 1 초 간격으로 쪼그려 앉았다가 일어나는 동작을 3 분간 반복하여 진행한 직후에 진행하였다.

손목형 심박수 측정 장치와 포화도 측정기를 동일 피검자에 게 적용하여 심박수를 측정하였다. 피검자의 왼쪽 손목에 손목 형 심박수 측정 장치를 착용하고 오른쪽 손가락의 검지에 $\mathrm{MP} 110$ 의 probe를 장착하였다.

\section{4. 통계분석}

손목형 심박수 측정 장치와 $\mathrm{MP} 110$ 을 이용하여 측정한 안정 상태와 운동 직후의 심박수를 비교하고 동일한 기기에서 측정 한 안정 상태와 운동 직후의 심박수를 비교하였다. SPSS Statistics 17.0 for Windows(SPSS. USA)프로그램을 이용 하여 Wilcoxon Signed Ranks Test를 시행하였다 $(p<0.05)$.

\section{III. 연구 성적}

\section{1. 안정시 두 기기 간의 심박수 비교}

통계학적으로 유의한 차이를 보이지 않았으며 $(p<0.05)$ Fig. 5는 10 명의 시간당 평균값을 막대 그래프로 나타낸 것이다.

\section{2. 운동 직후 두 기기 간의 심박수 비교}

통계학적으로 유의한 차이를 보이지 않았으며 $(p<0.05)$ Fig. 6 은 10 명의 시간당 평균값을 막대 그래프로 나타낸 것이다.

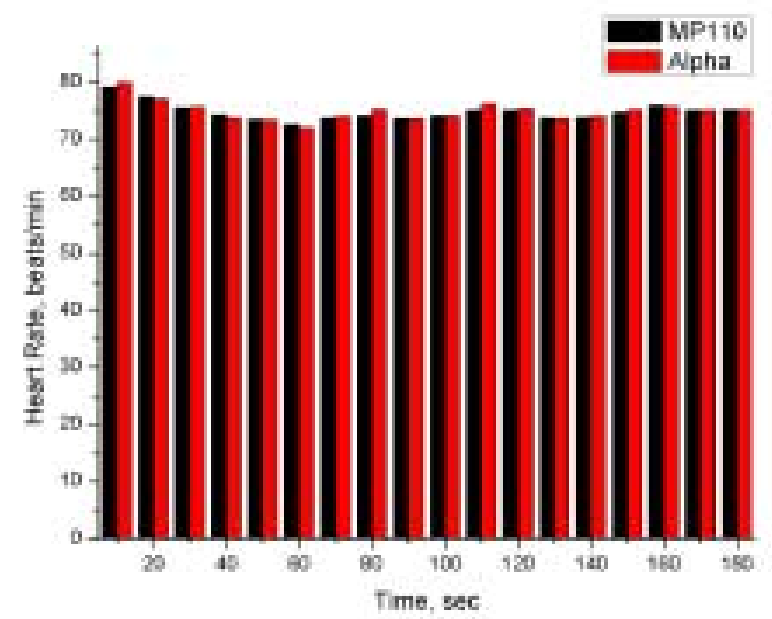

Fig. 5. Bar graph shows average heart rate per minute for 3 minutes during resting condition.

\section{3. 안정시와 운동 직후의 심박수의 비교}

1) MP110을 이용한 경우

$\mathrm{MP} 110$ 을 이용하여 측정한 안정시와 운동 직후의 심박수의 값을 분석한 결과 유의한 차이가 있었으며 $(p<0.05)$ 그래프로 나타내었다(Fig. 7).

2) 손목형 심박수 측정 장치를 이용한 경우

손목형 심박수 측정 장치를 이용하여 측정한 안정시와 운동 직후의 심박수의 값을 분석한 결과 유의한 차이가 있었으며 $(p<0.05)$ 그래프로 나타내었다(Fig. 8).

\section{IV. 총괄 및 고찰}

오랜 시간 치과에 대한 거부감으로 소아가 진료실에서 보이 는 행동 양상은 치과의사가 극복해야하는 장애로 작용하였다. Fanny 등ㄱㅇㅢ 연구에 따르면 동일한 발치 시술을 시행할 때 나 이가 어릴 수록 더 많은 두려움을 느끼는 것으로 나타났다.

소아 환자가 치과진료실에서 치료받는 과정에서 받는 스트레 스를 평가하는 방법은 CFSS-DS와 같은 설문을 통한 방법이 일반적이다. 설문은 치과 치료 전이나 치료 후에 평가를 진행하 며 본인 외에 보호자와 함께 진행하기도 한다. Gunilla 등의 의 2007년 리뷰에 따르면 DFA(Dental Fear and Anxiety)와 $\mathrm{DBMP}$ (Dental Behavior management problem)을 평가하 기 위해 1) 환아의 행동 반응을 직접 관찰하는 방법과 2) $\mathrm{psy}^{-}$ chometric scale을 이용하여 환아 본인 스스로 혹은 동반했던 부모가 평가하는 방법이 대표적이라고 하였다. 일반적으로 사 춘기 시기의 환아는 직접 평가를 하지만 13 세 이하의 환아의 경우 부모가 평가를 하는데 이러한 경우 환아가 실제로 느꼈던 것과 부모의 평가가 일치하기 매우 힘든 것으로 알려져 있달. 또한 많은 스트레스가 유발되는 상황의 경우 기억력에 대한 신

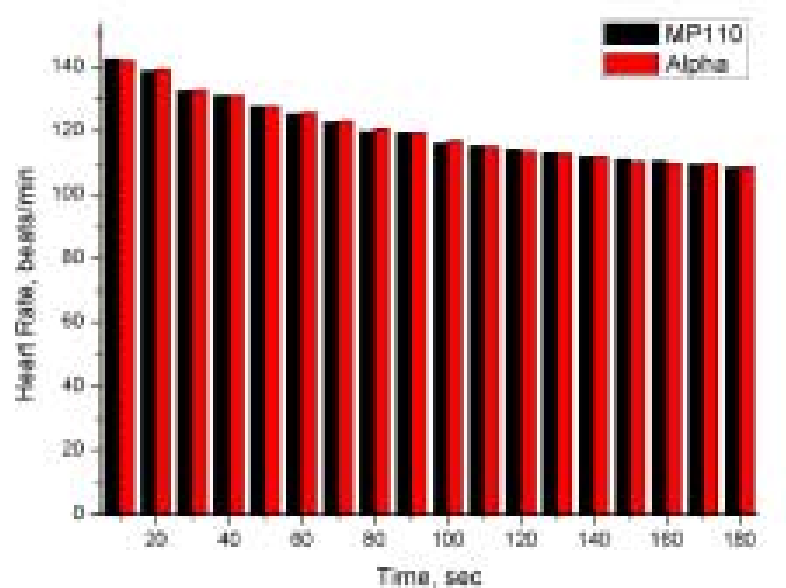

Fig. 6. Bar graph shows average heart rate per minute for 3 minutes after exercise. 


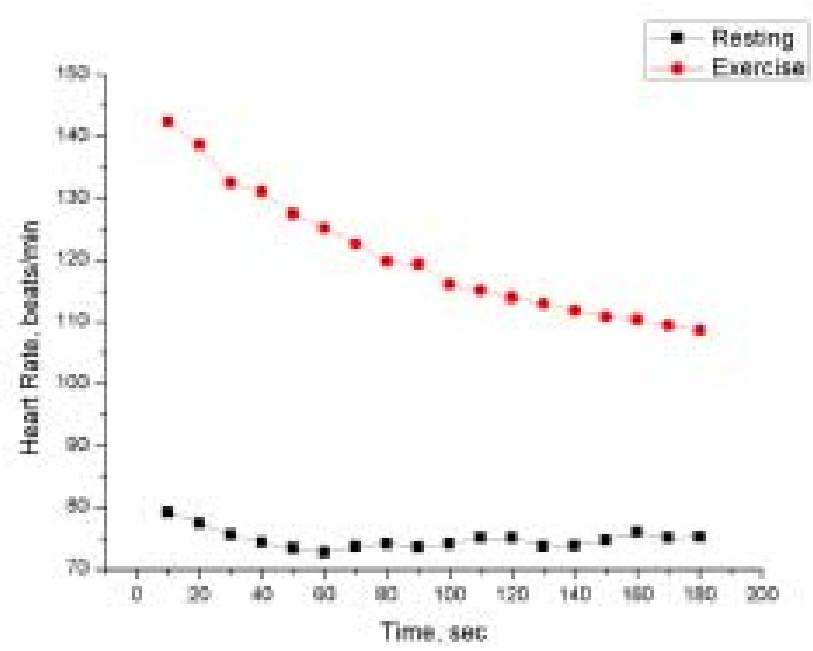

Fig. 7. Graph shows detected heart rate/min using MP110 for two different conditions.

빙성을 더욱 떨어지는 것을 고려할 때 ${ }^{12)}$ 설문을 통한 평가 방법 은 환아가 치과 치료 과정에서 경험하는 심적 상태를 수치화하 고자 하는 적극적인 형태의 의미는 있으나 결과에 대한 신빙성 과 유용성에 관한 고려가 필요하며 특히 진료 과정에 대한 전체 적인 부정적 의견을 보이는 경우에는 특정 치료 과정에 대한 거 부감을 명확하게 파악하기 힘든 문제가 있다.

환아 혹은 보호자의 주관적인 평가와 기억력에 의존하는 설 문조사 방식이 아닌 실제 환아가 느끼는 스트레스를 객관적인 방법으로 파악하기 위해 신체 반응에 대한 연구가 이루어 졌다. 기존에는 시상하부 뇌하수체 부신 시스템에 의해 분비되는 cortisol을 측정하는 방법이 대표적이었으나 최근에는 자율신경계 의 반응을 이용한 heart rate variability (HRV)을 측정하는 방법이 각광을 받고 있당. 스트레스와 관련한 생징후 측정을 위해 심박수와 혈압을 동시에 측정하는 연구가 있었다. 이 가운 데 심박수와 혈압을 이용하는 방법에서 심박수는 스트레스와의 관련이 있음이 증명되었으나 ${ }^{6.7)}$ Fanny 등 ${ }^{7)}$ 은 혈압이 스트레스 와 관련이 있다고 한 반면, Frank 등은 심박수와 달리 혈압은 실제 영향이 없다고 보고하였다. 이러한 상반된 의견과 별개로 성인과 다르게 소아는 심박수가 떨어질 경우 혈압을 유지하기 위한 보상 기전이 발달해 있지 않기 때문에 심박수는 혈압의 상 태를 나타내는 지표로 사용할 수 있다 ${ }^{13)}$ 는 것을 전제로 할 경우 소아치과에 내원하는 환아의 심박수 측정은 더 많은 의미를 포 함하게 된다.

환자의 심박수를 측정하기 위해 우선 선택할 수 있는 것은 포화도 측정기이며 포화도와 심박수의 동시 측정이 가능하나 손가락이나 발가락에 장착하는 probe가 탈락할 경우 측정이 중 단되는 문제 뿐 아니라 환자의 움직임에 의해서 probe에 있는 센서에 오차 신호(error signal)가 포함 되므로 기기의 신빙성 이 떨어진다 ${ }^{14)}$. 이러한 특성은 움직임이 없는 진정법 시행 상태 가 아닌 일반적인 치과 치료 시행시 환자의 생징후를 특정하기

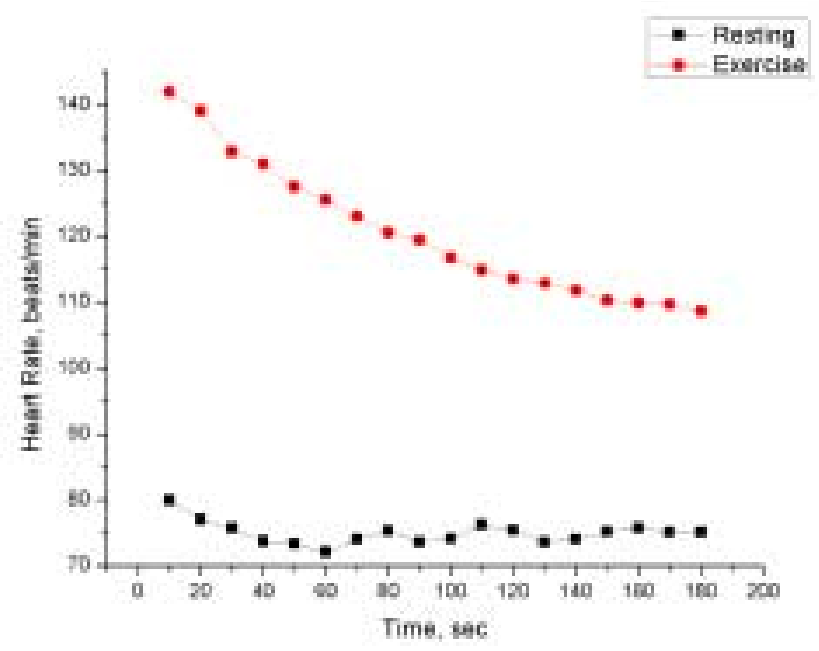

Fig. 8. Graph shows detected heart rate/min using Alpha for two different conditions.

위한 장치로는 한계가 있다. 또한 손가락이나 발가락을 이용하 기 때문에 손톱이나 발톱에 바니쉬가 발라져 있는 경우에도 온 전한 data를 얻을 수 없다. 이와 같은 문제를 해결하기 위한 방 법으로 probe 대신 센서를 피부에 패치 (patch)형태로 접착하 여 장착하는 방법도 소개되고 있지만 ${ }^{13)}$ 신호를 분석하여 수치화 시켜주는 장치의 부피와 센서가 유선으로 연결되어 있다. 이러 한 형태는 환자가 자신의 신체에 무언가 장치가 설치되어있다 는 것에 대한 인지 및 거부감을 유발하며 이로 인한 추가적인 스트레스가 발생할 수 있다. 이러한 기기적 특징으로 인한 문제 를 해결하기 위하여 최근에는 무선 형태로 개발된 다양한 기기 가 소개되고 있다. 가슴에 스트랩(strap) 형태로 장착하여 $\mathrm{RF}$ (radio frequency)전달 방식으로 신호를 보내주는 심박수 측정 장치부터 손가락에 창작하는 기기에 대한 개념까지 소개 되고 있다 ${ }^{15)}$.

최근에는 운동성에 문제를 일으키지 않으며 손쉽게 상태의 확인이 가능한 손목형 운동량 측정 기기가 소개되고 있다. 기존 의 손목형 기기는 GPS를 이용한 이동 경로 및 이동 거리와 속 도를 측정하는 장치로 미리 입력한 운동자의 키와 질량을 바탕 으로 한 칼로리 소모량과 운동량을 측정하는 것이 대부분이다. $\mathrm{MIO}$ 사의 Alpha는 심박수를 실시간으로 지속적으로 측정하는 최초의 손목형 기기다. Alpha는 원래 운동 중인 상태에서 선수 스스로 현재의 심박수를 확인하거나 멀리 떨어진 위치에서 선 수의 상태를 확인하기 위한 목적으로 개발되었기 때문에 심박 수를 눈으로 쉽게 인지할 수 있도록 1.2인치 Negative dot matrix 화면상의 대부분의 영역을 숫자로 보여준다. 또한 블루 투스 4.0 을 지원하는 스마트 기기와 연결이 가능하여 일정 거 리에서 장치를 장착한 이의 심박수를 실시간으로 측정할 수 있 다. 이러한 특징은 환아의 행동 조절이 안되어 몸을 움직이거나 기기가 장착된 손을 흔들어 기기 상에 나타나는 수치를 직접 확 인할 수 없는 경우에 일정 거리 떨어진 기기에서 환아의 심박수 


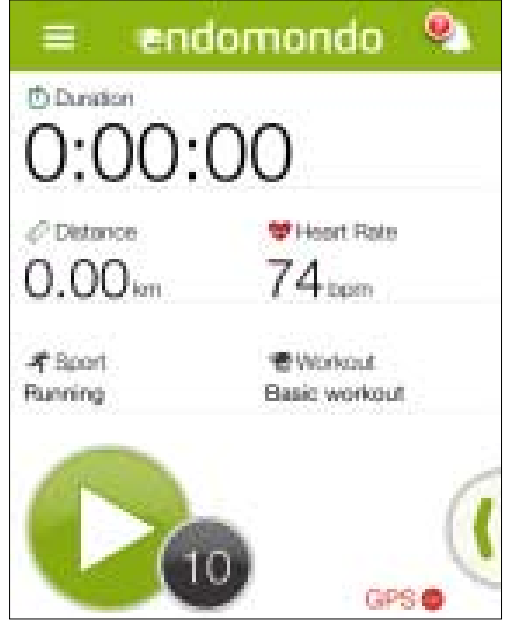

Fig. 9. Heart Rate monitoring app endomondo for iOS endomondo paired with Alpha and showing heart rate.

를 실시간으로 확인할 수 있도록 해준다. 손목에 장착하여 움직 임에 영향을 받지 않고 지속적으로 심박수를 전송할 수 있는 기 기는 운동 상황이 아닌 일상에서도 사용이 가능하며 수면 무호 흡 상태나 전신적인 이상으로 나타나는 심박수의 변화를 실시 간으로 스테이션이나 다른 경고 장치와 연동할 수도 있을 것이 다. 원격으로 심박수를 측정하기 위한 앱은 $\mathrm{iOS}$ 와 안드로이드 버전을 개발되어 사용 가능하다(Fig. 9).

Alpha는 손목과 맞닿는 부위에 있는 두 개의 LED 광원과 광학 센서 cell이 피부의 하방에 있는 혈액의 부피를 측정하여 심박수를 측정한다. 포화도 측정기는 손가락이나 발가락에 probe를 이용하기 때문에 측정하는 위치가 다르기는 하나 $\mathrm{LED}$ 광원에 대한 반응성 정도를 통해서 수치를 나타내 준다는 이론적인 배경의 공통점을 갖고 있다. 또한 포화도 측정기가 보 여주는 측정치는 매 단위로 측정되는 시점 이전의 몇 개의 측정 치까지를 포함하여 평균을 하는가에 따라 그 반응성의 차이가 발생하기 때문에 기기 간에 표현되는 수치상의 차이가 발생할 수 있다 ${ }^{14)}$. 이번 연구를 통하여 기 출시된 포화도 측정기와 비교 할 때 손목형 심박수 측정 장치의 서로 다른 알고리즘에도 불구 하고 유의한 차이를 보이지 않았다. 피검자에게 동일한 형태의 운동을 실기하기 위해 반복적이고 단순한 것으로 진행을 하였 으며 실제로 이러한 운동이 심박수의 증가를 유발하고 또한 안 정시와 비교할 때 유의한 차이가 보임을 알 수 있었다. 기 출시 된 포화도 측정기가 표준 기기로서의 의미를 부여할 수 있는가 에 대해서는 아쉬움이 있지만 심박수만을 측정하는 경우와 스 트레스에 의하여 심박수의 변화상을 확인하기 위한 실 사용에 적용하는데 문제가 없는 것으로 사료된다.

현재까지 개발된 Alpha용 app은 구간별 기록 저장 기능이 없어 향후 이러한 기능이 추가될 경우 환자가 치과 치료 과정에 서 각 단계별로 보이는 심박수의 변화상을 기록함으로써 체계 적인 정리와 환자별 맞춤 진료가 가능할 것으로 사료된다.
치과에 내원한 환아에게 대기실에서 거부감 없이 손목 시계 형 심박수 측정 장치를 장착하고 진료실로 들어와 진료를 진행 하고 진료실 문을 나설 때까지의 심박수를 지속적으로 측정함 으로써 가장 많은 스트레스를 유발하는 치료 과정을 실시간으 로 확인이 가능하고 이후에 기록된 내용을 바탕으로 향후 재 내 원시 환아가 측정 치과 치료 과정으로 인하여 유발되는 스트레 스를 최소화시키기 위해 더욱 주의함으로써 보다 만족스러운 치료가 가능할 것으로 사료된다.

\section{V. 결 론}

안정 상태나 운동직후의 두 상태 모두 기존의 포화도 측정기 의 심박수 측정결과와 손목형 심박수 측정장치의 결과와 차이 가 없었다 $(p<0.05)$. 따라서 환아의 심박수를 측정하기 위한 장치로 의미가 있을 것으로 사료되며 차후 지속적인 심박수의 측정을 통하여 치과 치료로 인하여 발생하는 스트레스의 측정 을 통하여 공포와 불안감을 감소시키기 위한 객관적인 지표로 의 활용에 대한 연구가 가능할 것으로 사료된다.

\section{References}

1. Klingberg G, Broberg AG : Dental fear/anxiety and dental behaviour management problems in children and adolescents: a review of prevalence and concomitant psychological factors. Int, J Paediatr Dent, 17:391-406, 2007.

2. Winer GA : A review and analysis of children's fearful behavior in dental settings. Child Dev, 53:11111133, 1982.

3. De Los Reyes A, Kazdin AE : Measuring informant discrepancies in clinical child research. Psychol Assess, 16:330-334, 2004.

4. Cuthbert MI, Melamed BG : A screening device: children at risk for dental fears and management problems. ASDC J Dent Child, 48: 432-436, 1982.

5. West GA, Reid KH, Bastawi AE : Autonomic Responses to Dental Procedures in Pedodontic Patients During a Standard Restoration Session. J Dent Res, 62:728-732, 1983.

6. Beck FM, Weaver JM $2^{\text {nd }}:$ Blood pressure and heart rate responses to anticipated high-stress dental treatment. J Dent Res, 60:26-29, 1981.

7. Liau FL, Kok SH, Chang HH, et al. : Cardiovascular influence of dental anxiety during local anesthesia for tooth extraction. Oral Surg Oral Med Pathol Oral Radiol Endod, 105:16-26, 2008.

8. Michels N, Sioen I, De Henauw S, et al : Children's heart rate variability as stress indicator: association 
with reported stress and cortisol. Biol Psychol, 94: 433-440, 2013.

9. Costin A, Costin N, Marchlinski F. et al. : Effect of exercise on heart-rate response to mental stress in teenagers. Eur J Prev Cardiol, 20:593-596, 2013.

10. Houser MM, Rosen L, Craig WA, et al. : Exercise heart rate monitors for anxiety treatment in a rural primary care setting: a pilot study. Fam Med, 45: 615-621, 2013

11. Kim HN, Baik BJ, Kim JG, et al. : Pulse Rate and Oxygen Saturation in Children druing Routine Restorative Dentistry. J Korean Acad Pediatr Dent, 35(1):65-72, 2008.

12. Chu JA, Frey LM, Matthews JA, et al. : Memories of childhood abuse: dissociation, amnesia, and cor- roboration. Am J Psychiatry, 156:749-755, 1999.

13. Jeffrey A, Avery DR, McDonald RE : McDonald's and Avery's dentistry for the child and adolescent, 9th ed. Mosby, St. Louis, 225, 2011.

14. Yoo SH, Kim EH, Kim JS, et al. : Comparative Study of Several Type Pulse Oximeter and Oxygen Saturation Extracted from Them, J Korean Acad Pediatr Dent, 27(4):494-498, 2000.

15. Jang IH, Sim KB : Ring-type Heart Rate Sensor and Monitoring system for Sensor Network Application, Journal of Korean institute of intelligent systems, 17:619-625, 2007.

16. Anderson JA : Respiratory monitoring during pediatric sedation: pulse oximetry and capnography. Pediatr-Dent, 10:94-101, 1988. 
국문초록

\section{최근 소개된 손목형 심박수 측정 장치의 유용성에 관한 연구}

\section{유승훈}

단국대학교 치과대학 소아치과학 교실

소아 환자가 치과 진료실에서 느끼는 불안감과 공포에 의해 발생하는 스트레스를 측정하기 위한 다양한 방법이 있다. 치료 받은 환아나 보호자를 통한 설문을 이용하는 방법과 생체 반응을 측정하는 방법이 가장 많이 사용되고 있다. 스트레스와 관 련한 심박수를 측정하는 방법으로 가장 많이 사용하는 것은 포화도 측정기가 있으나 움직이는 소아에게는 적절하지 못한 문 제가 있다. 이러한 단점을 극복하기 위해 최근 개발되어 소개된 손목형 심박수 측정 장치(Alpha, MIO, USA)를 포화도 측 정기(MP110, MECKIS, Republic of Korea)와 비교하였으며 이를 위해 10명의 성인을 대상으로 안정시와 운동 직후의 심 박수를 두 기기를 동시에 장착하여 측정된 데이터를 Wilcoxon Singed Rank test를 시행하였다 $(p<0.05)$. 두 기기에서 측 정된 데이터 간의 유의한 차이가 없었다 $(p<0.05)$.

주요어: 스트레스, 심박수, 손목형 심박수 측정 장치 